\title{
Revision of the Psammothidium manguinii complex (Bacillariophyta) in the sub-Antarctic Region with the description of four new taxa
}

\author{
Bart VAN DE VIJVER
}

\author{
Meise Botanic Garden, Research Department, Nieuwelaan 38, B-1860 Meise, Belgium; Corresponding author \\ e-mail: bart.vandevijver@plantentuinmeise.be \\ University of Antwerp, Department of Biology, ECOBE, Universiteitsplein 1, B-2610 Wilrijk, Antwerpen, Belgium
}

\begin{abstract}
Psammothidium manguinii is a common constituent of the limnoterrestrial diatom flora of the Antarctic Region. The species shows a broad variability in several morphological and morphometrical features such as valve outline, valve width, striation pattern and length/width ratio. Analysis of the type material of Achnanthes manguinii, described by HustedT in 1952, and A. manguinii var. elliptica, described by Manguin two years later, together with an analysis of a large number of $P$. manguinii populations from the sub-Antarctic Region (with samples from all major islands in the southern Atlantic, Indian and Pacific Ocean), resulted in a clear morphological revision of the species. Four new species are described, $P$. acutomanguinii sp. nov., $P$. antarcticum sp. nov., P. mannensianum sp. nov. and $P$. hodgsonii Van de Vijver et Verleyen sp. nov., whereas the former variety elliptica is brought to species level: P. ellipticomanguinii nom. et stat. nov. The morphology, ecology and distribution of all species are discussed and a morphological comparison is made.
\end{abstract}

Keywords: Antarctic Region, type material, revision, Psammothidium, monoraphid diatoms

\section{INTRODUCTION}

Monoraphid diatoms represent a highly diverse group of non-marine diatoms in the sub-Antarctic Region (VAN DE ViJver et al. 2002; Le CoHu 2005; Kopalová et al. 2016; ZIDAROVA et al. 2016). Originally belonging to either the genus Achnanthes s.l. or Cocconeis, the entire group underwent a serious revision in the nineties of last century (e.g., BukTiYarova \& Round 1996). This led to a split of the original genus Achnanthes s.l. into multiple (often newly described) genera such as Achnanthes s.s., Achnanthidium, Skabitschewskia, Gliwiczia, Eucocconeis, Planothidium, Psammothidium, Karayevia, Platessa or Lemnicola (BukHTIYAROVA \& Round 1996; Round \& BuKTIYAROva 1996; Round \& BASSON 1997; KINGSTON 2003; KULIKOVSKIY et al. 2013, 2015). Six of these (Achnanthes s.s., Achnanthidium, Planothidium, Psammothidium, Platessa and Lemnicola) are now reported from the (sub-)Antarctic Region. Most species in these six genera are considered having a restricted biogeographical distribution in this region and several of these species were described more than 50 years ago from the Antarctic region. KellogG \& KeLLOGG (2002) list all records of monoraphid diatoms in the Antarctic Region. MANGUIN (in BourRelly \& MANGUIN 1954) described 11 new taxa (all placed in the genus Achnanthes s.l.) from the sub-Antarctic the Kerguelen Archipelago, located in the southern Indian Ocean. Two years prior to this publication, HustedT already described 2 new Achnanthes taxa, A. manguinii Hustedt and A. pseudolanceolata Hustedt from the same Kerguelen Archipelago (Hustedt 1952). The latter species proved later to be a younger synonym of Achnanthes aueri Krasske, described in 1949 from southern Chile (KRASSKE 1949). A first comprehensive overview of the monoraphid diatoms from the sub-Antarctic region was produced by LE COHU \& MAILLARD in 1983 listing and illustrating (using both LM and SEM observations) 35 taxa observed during a diatom survey of the Kerguelen Archipelago. In 2005, LE COHU revised the Kerguelen monoraphid diatom flora which resulted in a better description of 24 taxa. VAN DE VIJVER et al. (2002) made a similar inventory for the near Crozet archipelago, described four new taxa in the genera Achnanthes s.s., Planothidium and Psammothidium, and transferred another seven from Achnanthes s.1. to Achnanthidium, Planothidium and Psammothidium. In 2011, a new Cocconeis species, C. crozetensis Romero et Van de Vijver was described from the Crozet Archipelago (RoMERo \& VAN DE VIJVER 2011), at present, the only freshwater Cocconeis species known from the sub-Antarctic Region. Recently the monoraphid diatom flora of another region 
in Antarctica, the Maritime Antarctic Region, located in the southern Atlantic Ocean was revised (ZIDAROva et al. 2016), resulting in the description of eleven new taxa on a total of 26 recorded taxa. Especially the species complexes around Planothidium lanceolatum (Brébisson ex Kützing) Lange-Bertalot (VAN DE VIJVER et al. 2013), Psammothidium germainii (Manguin) Sabbe (VAN DE VIJVER et al. 2016) and Achnanthidium minutissimum (Kützing) Czarnecki (ZIDARova et al. 2009; VAN DE ViJVER \& Kopalová 2014) were revised.

Recently, new investigations on the freshwater and terrestrial diatom flora of the sub-Antarctic islands, revealed the presence of several unknown monoraphid taxa that could not be identified using the currently available literature or have always been force-fitted into already established taxa. One of the typical Antarctic species that presumably showed a broad morphological variability and a very large Antarctic biogeographical distribution, is Psammothidium manguinii (Hustedt) Van de Vijver. Originally, this species was described in 1952 by HusteDT as Achnanthes manguinii from the Kerguelen Archipelago and although no precise indication is given where the exact sampling locality is situated, Hustedt confirmed that the species was "häufig in Süsswassertümpeln (abundant in freshwater pools)" (HustedT 1952). In his description, Hustedt mentions the 3-4 undulations of the valve margins and the slightly protracted, rostrate apices. Two years later, Manguin (in BOURRELLY \& MANGUIN 1954) separates valves lacking the typical marginal undulations as Achnanthes manguinii var. elliptica Manguin stating that the margins are clearly convex with subrostrate apices. Both taxa showed also some morphometrical differences with $A$. manguinii having 24-28 striae in $10 \mu \mathrm{m}$ and the var. $e l$ liptica only 20 in $10 \mu \mathrm{m}$ (HuSTEDT 1952; BouRRELly \& MANGUIN 1954). Moreover, the var. elliptica has a valve width according to Manguin of 7.5-8 $\mu \mathrm{m}$ whereas the nominate variety is only 5-7 $\mu \mathrm{m}$ wide. Together with the variety elliptica, Bourrelly \& MANGuin (1954) also showed one valve showing a quite different valve outline, size and central area, despite having pronounced three marginal undulations (see BOURRELLY \& MANGUIN 1954, fig. 14c). LE COHU \& MAILlARD (1983) raised the first doubts whether both taxa should be separated or not stating "il n'y a pas de difference avec l'espèce (there is no difference with the species)". Le COHU \& MAILlaRD (1983, Figs 150, 151) also showed two broader valves with more pronounced marginal undulations. LANGEBERTALOT \& KRAMMER (1989) considered the var. elliptica to be only a morphological different form of $A$. manguinii. VAN DE VIJVER et al. (2002) transferred the species to the genus Psammothidium and included the var. elliptica in P. manguinii as a synonym stating that several intermediate forms could be found, a statement confirmed by Le COHU (2005). ZIDAROva et al. (2016) reported the species from the Maritime Antarctic Region but curiously enough only valves that would be classified in the var. elliptica were observed whereas valves with the typical triundulate margins were absent. JÜTTNER \& VAN DE VIJVER (2018) reported A. manguinii from the Falklands/Islas Malvinas in the southern Atlantic Ocean but the illustrated valves all belonged to the former variety elliptica.

A survey of the genus Psammothidium on the sub-Antarctic islands in the southern Indian and Pacific Ocean, indicated that at least four different taxa in the P. manguinii-complex could be separated. The present paper revises these taxa and reanalyzes the type material or slide of both Achnanthes manguinii Hustedt and its variety elliptica Manguin. Four new species are described: Psammothidium mannensianum sp. nov. from Campbell Island (southern Pacific Ocean), P. hodgsonii Van de Vijver et Verleyen sp. nov. from Macquarie Island (southern Pacific Ocean), P. acutomanguinii sp. nov. from Heard Island (southern Indian Ocean) and $P$. antarcticum sp. nov. from the entire sub-Antarctic and Maritime Antarctic region whereas $A$. manguinii var. elliptica is revised and brought to species level: P. ellipticomanguinii stat. et nom. nov. from the southern Indian Ocean islands. All previously published iconographic data of P. manguinii (according to KellogG \& KellogG, 2002) are re-investigated together with a reanalysis of all samples in which $P$. manguinii was reported in VAN DE VIJVER et al. (2001, 2002, 2004 and 2008), and newly acquired samples from Campbell Island and Macquarie Island (Van de Vijver, unpubl. res.).

\section{Material ANd Methods}

Samples were collected during several field trips from various terrestrial and aquatic habitats on most sub-Antarctic Islands in the southern Atlantic (South Georgia), Indian (the Kerguelen Archipelago, the Crozet Archipelago, Heard Island, Prince Edward Islands) and Pacific (Macquarie Island, Campbell Island) Oceans (Fig. 1). More information on the geology, climate and vegetation of these sampling localities and details on sampling methods and physicochemical analyses can be found in Hickmann \& VitT (1973), VAn DE ViJVER \& Beyens $(1996,1997)$ and VAN DE VIJVER et al. $(2001,2002,2004,2008)$.

Diatom samples were prepared following the method described in VAN DER WERFF (1955). Small parts of the samples were cleaned by adding $37 \% \mathrm{H}_{2} \mathrm{O}_{2}$ and heating to $80{ }^{\circ} \mathrm{C}$ for about one hour, followed by addition of $\mathrm{KMnO}_{4}$. After digestion and centrifugation $(3 \times 10$ minutes at $3700 \mathrm{~g})$, the material was diluted with distilled water to avoid excessive concentrations of diatom valves. Cleaned diatom valves were mounted in Naphrax ${ }^{\circledR}$. Samples and slides are stored at the BR-collection (Belgium). The slides were analyzed using an Olympus BX53 microscope, equipped with Differential Interference Contrast and the UC30 camera connected to the Cell Sense Standard program. For scanning electron microscopy (SEM), part of the suspension was filtered through polycarbonate membrane filters with a pore diameter of $1 \mu \mathrm{m}$, pieces of which were fixed on aluminum stubs after air-drying. The stubs were sputter-coated with $10 \mathrm{~nm}$ of Pt-Pd and studied in a Zeiss Ultra microscope at $3 \mathrm{kV}$ (Natural History Museum, London, UK) and a JEOL JSM-7100F at $2 \mathrm{kV}$ (Meise Botanic Garden, 
Belgium). Terminology is based on Hendey (1964), Ross et al. (1979) and Round et al. (1990). Stria density was determined by counting striae in $5 \mu \mathrm{m}$, starting near the valve center to one of the apices. For each new taxon, the number of specimens measured at random on the type slide is indicated $(n=X)$.

For this study, the type material of Achnanthes manguinii and Achnanthes manguinii var. elliptica has been investigated:

- Achnanthes manguinii Hustedt in HustedT (1952), material AT312, from the Hustedt collection, AWI institute, Bremerhaven, Germany

- Achnanthes manguinii var. elliptica Manguin in BOURRELlY \& MANGUin (1954), sample 179, slides AD9084, AD9086AD9090, in the herbarium of the Muséum national d'Histoire Naturelle (MNHN) in Paris, France

For comparison, several populations of Psammothidium manguinii observed on the islands in the southern Indian, Pacific and Atlantic Oceans have been analysed using light microscopical observations. The following samples have been investigated in more detail.

- HE-Q252 (Heard Island, crater SW of Corinth Head, coll. date 09/02/2001, leg. N.J.M. Gremmen) (5300'33.1"S,73²4'29.9"E) - HE546 (Heard Island, West of Lavett Buff, coll. date 21/12/2000,

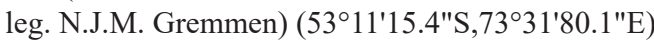

- KER-BM505 (the Kerguelen Archipelago, Val Studer, coll. date $15 / 01 / 2002$, leg. B. Van de Vijver) $\left(49^{\circ} 17^{\prime} 02.7^{\prime \prime S}, 70^{\circ} 03^{\prime} 07.3^{\prime \prime E}\right)$ - MAC8 LITE (Macquarie Island, 28/11/2013, leg. W. Van Nieuwenhuyze) (5442'59.6"S, 158 49'55.3"E)

- VITT 2433 (Mount Honey, Campbell Island, 31/12/1969, leg. D. Vitt) $\left(52^{\circ} 34^{\prime} \mathrm{S}, 169^{\circ} 10^{\prime} \mathrm{E}\right)$.

For a better characterization of the ecology of Psammothidium manguinii and its related taxa, all samples in which P. manguinii was found on the Southern Ocean islands, were re-investigated for this study. The biogeography of the (new) taxa was established based on the investigated samples from the Southern Ocean islands (VAN DE ViJver \& Beyens 1996, 1997; VAN DE VIJVER et al. 2001, 2002, 2004, 2008), new observations on Campbell and Macquarie Island material (VAN DE VIJVER,

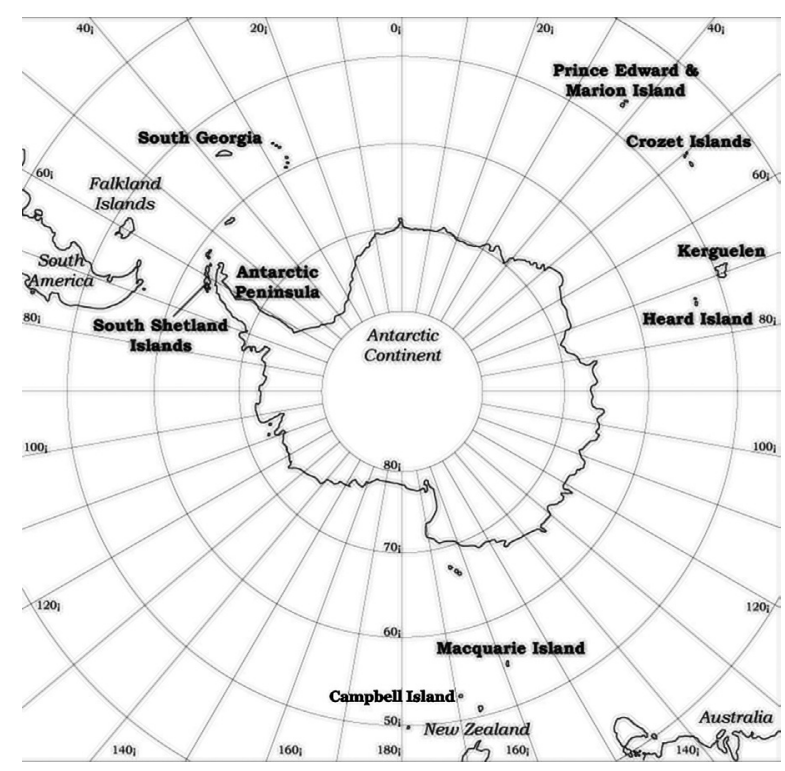

Fig. 1. Sketch map of the investigated islands and archipelagos in the (sub)-Antarctic Region. unpubl. res.) made during this study and all iconographic material that exists from earlier Antarctic and sub-Antarctic studies (KellogG \& KellogG 2002).

\section{RESULTS}

Psammothidium manguinii Hustedt in HuSTEDT (1952, p. 383, figs 52-56)

Original description (translated from the original Latin text by HustedT 1952): Valves elliptical with margins showing 3-4 undulations and rostrate to subcapitate apices. Length 13-18 $\mu \mathrm{m}$, width 5-7 $\mu \mathrm{m}$. Raphe valve with straight raphe. Axial area narrow. Central area a rather broad, rectangular fascia, almost reaching the valve margins. Striae radiate, $24-28$ in $10 \mu \mathrm{m}$, clearly punctate. Areolae in slightly undulating longitudinal rows, ca. 30-34 in $10 \mu \mathrm{m}$. Rapheless valve with moderately broad, lanceolate axial area. Transapical striae weakly radiate, ca. 24 in $10 \mu \mathrm{m}$, clearly punctata. Areolae similar to the raphe valve.

Morphology of the type population (Figs 2-25, 74-77) Light microscopy (Figs 2-25): Valves broadly lanceolate with clearly convex margins, showing 2-4 undulations, and clearly protracted, rostrate to weakly subcapitate apices. Valve dimensions $(\mathrm{n}=25)$ : length $12-18 \mu \mathrm{m}$, width 5-7 $\mu \mathrm{m}$, length/width ratio 2.2-3.0. Raphe valve: axial area narrow, linear, weakly widening towards the central area. Central area symmetrical, wedge-shaped, almost forming a fascia bordered by up to six shortened striae at the valve margins. Raphe filiform, straight, located on raised sternum. Central raphe endings straight, simple. Terminal raphe fissures not discernible in LM. Striae strongly radiate becoming almost parallel near the valve apices, 24-27 in $10 \mu \mathrm{m}$, clearly punctate. Areolae discernible, though hardly countable in LM. Rapheless valve: Axial area clearly lanceolate, broad. Central area formed by the widened axial area, never forming a fascia. Striae radiate throughout, 22-26 in $10 \mu \mathrm{m}$, composed of 5-6 relatively large areolae.

Scanning electron microscopy (Figs 74-77): Raphe valve (Figs 74, 76): Raphe located on a weakly raised, thickened sternum. External raphe branches straight. Central raphe endings straight, very short, simple to weakly drop-like expanded. Terminal raphe fissures short, straight, weakly expanded. Internally, central raphe endings shortly hooked to opposite sides. Terminal endings terminating on weakly developed helictoglossae. Striae uniseriate. External areola foramina rounded to squarish and even rectangular, around 40 in $10 \mu \mathrm{m}$. Virgae wider than the striae. Terminal areolae of each stria near the valve margin slit-like. On the valve mantle, striae continuing with one, slit-like areola. Mantle striae not entirely surrounding the valve, but interrupted at the valve apices. Internally, areolae usually rectangular. Terminal areolae in each stria clearly slit-like, often formed by 
fusing several areolae, occluded normally by individual hymenes but usually eroded. Virgae not raised, broader than the striae. Rapheless valve (Figs 75, 77): External axial and central area slightly depressed, showing faint ghost striae. Very small vestiges of a raphe visible on both apices (Fig. 75, arrows). Striae uniseriate composed of rectangular to rounded areolae. Areolae bordering the axial area larger than others and 1-2 terminal areolae near the valve margins slit-like. Mantle areolae slit-like, interrupted near the valve apices. Internally, axial and central area smooth, flat. Areolae rounded to almost rectangular. Several slit-like areolae present near the valve margins, internally separated by small silica struts. Virgae not raised, slightly broader than the striae.

Ecology and confirmed distribution: Psammothidium manguinii was observed on all investigated sub-Antarctic islands in the southern Indian and southern Pacific Ocean. The species seems to be absent in the Maritime Antarctic Region and on the islands in the southern Atlantic Ocean such as Gough Island and the Falkland Islands/Islas Malvinas (ZIDAROvA et al. 2016; JÜTTNER \& VAN DE VIJVER 2018).

Psammothidium manguinii is a common constituent of terrestrial moss vegetations and semi-wet, bare soils. Together with other Psammothidium taxa, such as $P$. germainii or $P$. stauroneioides (Manguin) Bukhtiyarova, it often dominates the flora in these samples. In aquatic moss samples, the species was only very rarely observed. One valve, reported as $A$. cf. manguinii was mentioned by HASSAN et al. (2011) in a paleo-study from central Argentina, although it may be the result of misidentification or forcefitting.

Remarks: Manguin (in BourRelly \& MANGUIN 1954) discusses $A$. manguinii found in his material collected by Dr. R. Arétas in 1950. In one of the samples ( ${ }^{\circ} 179$, spread over several slides), a nice population was observed (Figs 26-50). BouRRELLY \& MANGUIN (1954) reported the following valve dimensions: length $14-20 \mu \mathrm{m}$, width 5-7 $\mu \mathrm{m}, 20-28$ striae in $10 \mu \mathrm{m}$ for both valves.

Achnanthes manguinii var. elliptica Manguin in Bourrelly \& Manguin (1954, p. 22, figs 15a-b) (Figs 51-73)

Original description (translated from the original French text by Manguin in BourRelly \& MANGuin 1954): Valves with strongly convex margins and subrostrate, protracted apices. Length 16-17 $\mu \mathrm{m}$, width 7.5-8.0 $\mu \mathrm{m}$. Transapical striae radiate, 20 in $10 \mu \mathrm{m}$ for both valves.

The type material of the var. elliptica was collected on 10/03/1950 in a peatbog on the Kerguelen Archipelago (sample 179). Several slides were made from this material, all kept at the Manguin collection housed in the Musée d'Histoire naturelle de Paris (AD9084, 9086-9090). All slides were examined due to the rarity of the taxon. Besides a relatively large population of Psamothidium manguinii (Figs 26-50), several valves were observed (Figs 51-73) that might belong to the var. elliptica. However, the observed valves can be separated into two different groups based on differences in valve outline and valve dimensions. Only the valves of group 1 (Figs 51-61) correspond to the drawings and the descriptions that Manguin published in BourRelLY \& MANGUIN (1954) and will be considered representing the true Achnanthes manguinii var. elliptica as Manguin described it. The second group (Figs 62-73) will be described as a new species, Psammothidium antarcticum sp. nov.

Unfortunately, as only slides were available, no SEM observations on both taxa could be made. Therefore, several populations representing the two taxa, collected during later expeditions on the Kerguelen Archipelago (sample BM505, Figs 78-99) and Heard Island (sample HE546, Figs 100-130) were investigated using scanning electron microscopy. The population of $A$. manguinii var. elliptica from the Kerguelen Archipelago, observed in sample BM505, will be added hereby as epitype to the original material.

Lectotype (designated here): sample AD9090 (Museum d'Histoire naturelle de Paris, France)

Epitype (designated here): BR-4545 (Meise Botanic Garden, Belgium); sample KER-BM505 (Val Studer, the Kerguelen Archipelago, coll. date 15/01/2002, leg. B. Van de Vijver) (49¹7'02.7"S, $\left.70^{\circ} 03^{\prime} 07.3^{\prime \prime} \mathrm{E}\right)$

\section{Morphology of the type population (Figs 51-61)}

Light microscopy (Figs 51-61): Valves elliptical to elliptical-lanceolate with clearly convex, rounded, never parallel and straight, margins and protracted, rostrate to subrostrate apices. Valve dimensions $(n=10)$ : length 13.5-22.0 $\mu \mathrm{m}$, width 6.5-9.5 $\mu \mathrm{m}$, length/width ratio 2.0-2.5. Rapheless valve: Axial area very broad, lanceolate forming a broad central area. Central area never forming a fascia. Striae uniseriate, composed of several areolae, well discernible in LM. Striae, 22-23 in $10 \mu \mathrm{m}$, clearly radiate throughout the entire valve. Raphe valve: Axial area narrow, linear, gradually but distinctly widening towards the central area. Central area large, distinctly wedge-shaped, almost forming a fascia, bordering by several shortened marginal striae. Raphe filiform, straight. Central raphe endings straight, simple to weakly expanded. Terminal raphe fissures not discernible in LM. Striae strongly radiate and even geniculate throughout the entire valve, 22-24 in $10 \mu \mathrm{m}$. Areolae often visible in LM.

Scanning electron microscopy of the epitype (BM505) (Figs 96-99): Raphe valve (Figs 96, 98): Raphe located on a clearly thickened, broad, raised, sternum. External raphe branches straight. Central raphe endings straight, very short, clearly drop-like expanded. Terminal raphe fissures short, straight, weakly expanded. Internally, central raphe endings short, hooked into opposite sides. Terminal endings terminating on weakly developed helictoglossae. Striae uniseriate. External areola foramina 


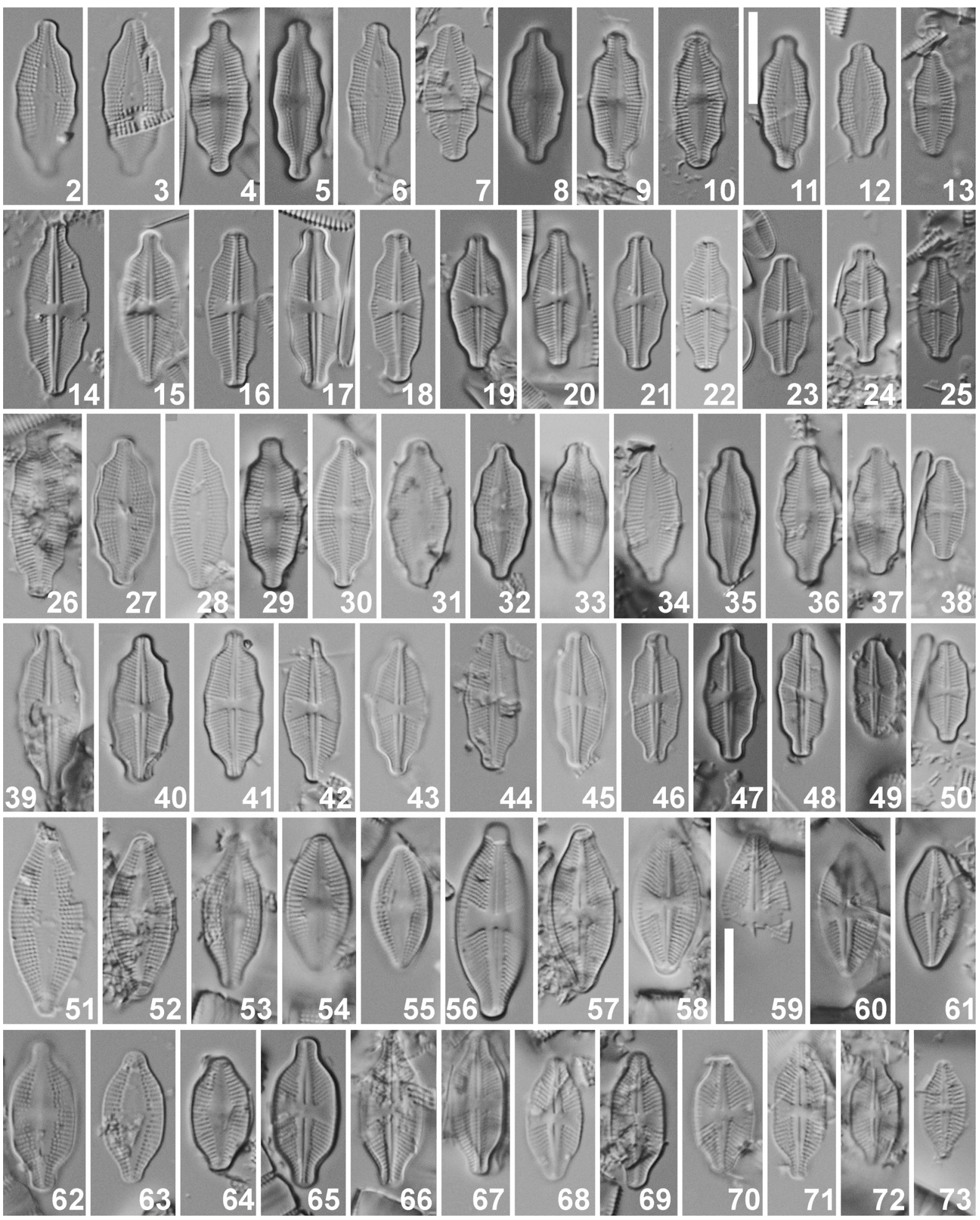

Figs 2-73. Psammothidium manguinii (Hustedt) Van de Vijver (Figs 2-50), P. ellipticomanguinii Van de Vijver stat. et nom. nov. (Figs 51-61) and $P$. antarcticum Van de Vijver sp. nov. (Figs 62-73); LM from historic material. Figs 2-25 P. manguinii, pictures taken from the type population (Sample AT312, Hustedt collection, Bremerhaven, Germany) showing rapheless (Figs 2-13) and raphe (Figs 14-25) valves. Figs 26-50 P. manguinii, pictures taken from sample 179 (Manguin collection, Muséum nat. d'Histoire naturelle, Paris, France) showing rapheless (Figs 26-38) and raphe (Figs 39-50) valves. Figs 51-61 P. ellipticomanguinii, pictures taken from the lectotype sample 179 (slides AD9084, 9086-9090, Manguin collection, Muséum nat. d'Histoire naturelle, Paris, France) showing rapheless (Figs 51-55) and raphe (Figs 56-61) valves. Figs 62-73 P. antarcticum, pictures taken from the type sample 179 (slides AD9084, 9086-9090, Manguin collection, Muséum nat. d'Histoire naturelle, Paris, France) showing rapheless (Figs 62-64) and raphe (Figs 65-73) valves. Scale bars represent $10 \mu \mathrm{m}$. 

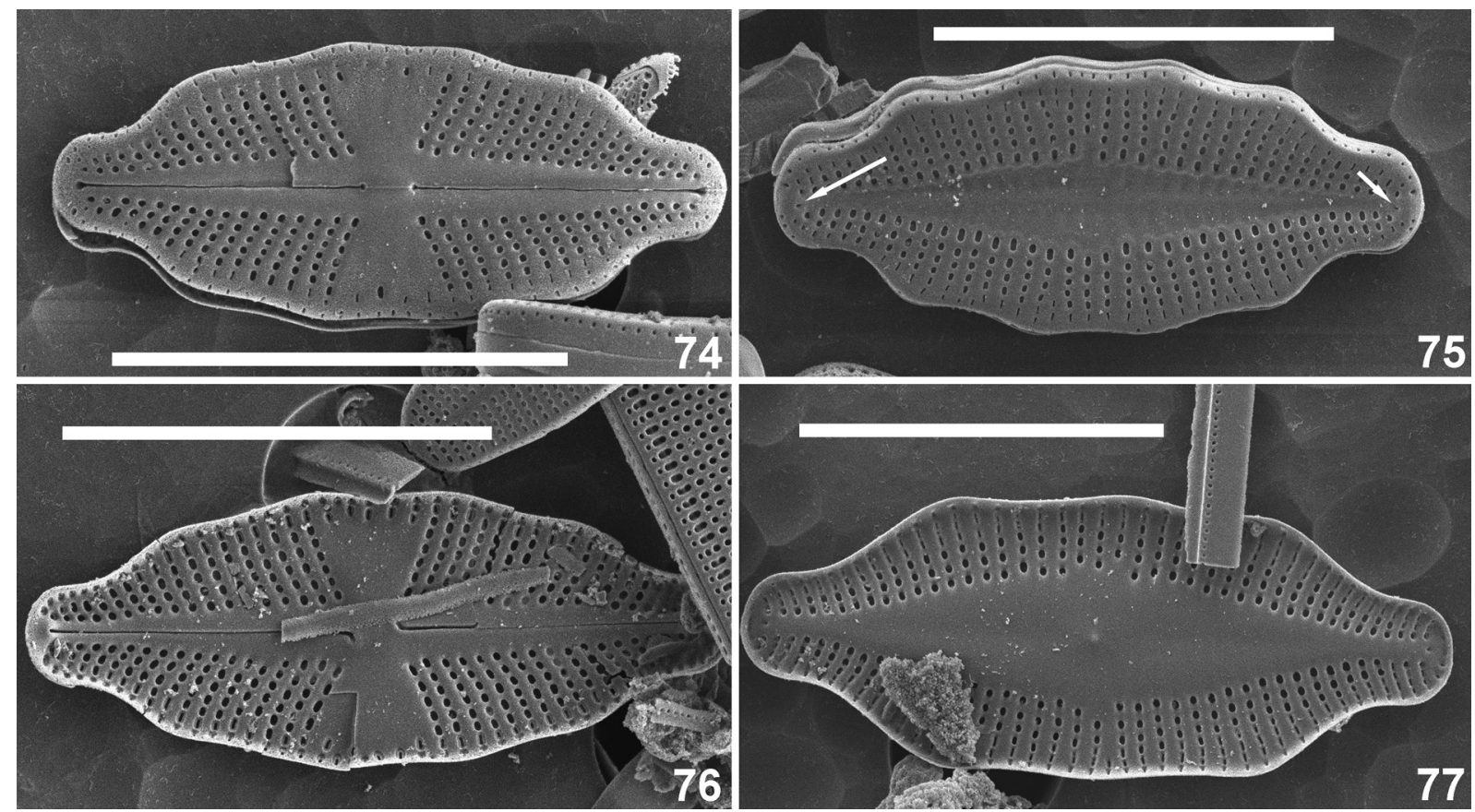

Figs 74-77. Psammothidium manguinii (Hustedt) Van de Vijver, SEM pictures taken from the type population (Sample AT312, Hustedt collection, Bremerhaven, Germany). Fig. 74. SEM external view of an entire raphe valve. Fig. 75. SEM external view of an entire rapheless valve. The arrows indicate the presence of vestigial raphe slits. Fig. 76. SEM internal view of an entire raphe valve. Fig. 77. SEM internal view of an entire rapheless valve. Scale bars represent $10 \mu \mathrm{m}$.

rounded to rectangular near the axial area, around 40 in $10 \mu \mathrm{m}$. Virgae wider than the striae. 1-2 terminal areolae of each stria near the valve margin slit-like. On the valve mantle, striae continuing with one, slit-like areola. Mantle striae not entirely surrounding the valve, but interrupted at the valve apices. Internally, areolae usually rectangular. Terminal areolae in each stria clearly slit-like, occluded normally by individual hymenes. Virgae not raised, broader than the striae. Rapheless valve (Figs 97, 99): External axial and central area slightly depressed, showing faint ghost striae. Vestigial raphe slits never observed. Striae uniseriate composed of rectangular to rounded areolae. Areolae bordering the axial area larger than others and 1-2 terminal areolae near the valve margins slit-like. Mantle areolae slit-like, interrupted near the valve apices. Internally, axial and central area smooth, flat. Areolae rounded to almost rectangular. Several slit-like areolae present near the valve margins, internally separated by small silica struts. Virgae not raised, slightly broader than the striae.

Ecology and confirmed distribution: Most populations of this taxon were observed on Ile Crozet (see VAN DE VIJVER et al. 2002, plate 29, figs. 26-30). The species seems absent on the Prince Edward Islands and on Heard Island whereas on the Kerguelen Archipelago, only a few populations were recorded. In the Maritime Antarctic Region, the taxon has never been reported (ZIDAROVA et al. 2016). The largest population on Ile de la Possession, the main island of the Crozet Archipelago, was found in wet mosses in the splash zone of a waterfall although the species was also recorded in a relatively dry soil sample, collected on a fellfield area. The sample was dominated by Angusticopula dickiei (Thwaites) Houk et al., several Humidophila taxa such as H. ingeae (Van de Vijver) R.Lowe et al. and H. crozetikerguelensis (Le Cohu et Van de Vijver) R.Lowe et al. and Psammothidium stauroneioides (Manguin) Bukhtiyarova. On the Kerguelen Archipelago, the taxon was mostly observed in seepage areas on rocks. This might indicate that the species can sustain short periods of drought when the seepage dries out or the waterfall disappears due to less precipitation.

Remarks: the population in sample BM505 has slightly different valve dimensions $(\mathrm{n}=25)$ : length $15-33 \mu \mathrm{m}$, width 7.5-11 $\mu \mathrm{m}, \mathrm{L} / \mathrm{W}$ ratio $2.1-2.6$ ).

\section{Description of new taxa \\ Psammothidium antarcticum sp. nov. (Figs 100-130) Description}

Light microscopy (Figs 100-126): Valves elliptical with parallel, straight (never clearly convex) margins and distinctly protracted, rostrate, occasionally truncated apices. Valve dimensions $(\mathrm{n}=40)$ : length 9-17.0 $\mu \mathrm{m}$, width 4-7 $\mu \mathrm{m}$, length/width ratio 2.1-2.6. Rapheless valve: Axial area broad, lanceolate widening at the central area. Central area never forming a fascia. Striae clearly radiate throughout the entire valve, 22-25 in 10 $\mu \mathrm{m}$, composed of several small areolae, well discernible in LM. Raphe valve: Axial area narrow, linear, gradually but distinctly widening towards the central area. Central area large, distinctly wedge-shaped, almost forming a fascia, bordering by several shortened marginal striae. Raphe filiform, straight. Central raphe endings straight, 


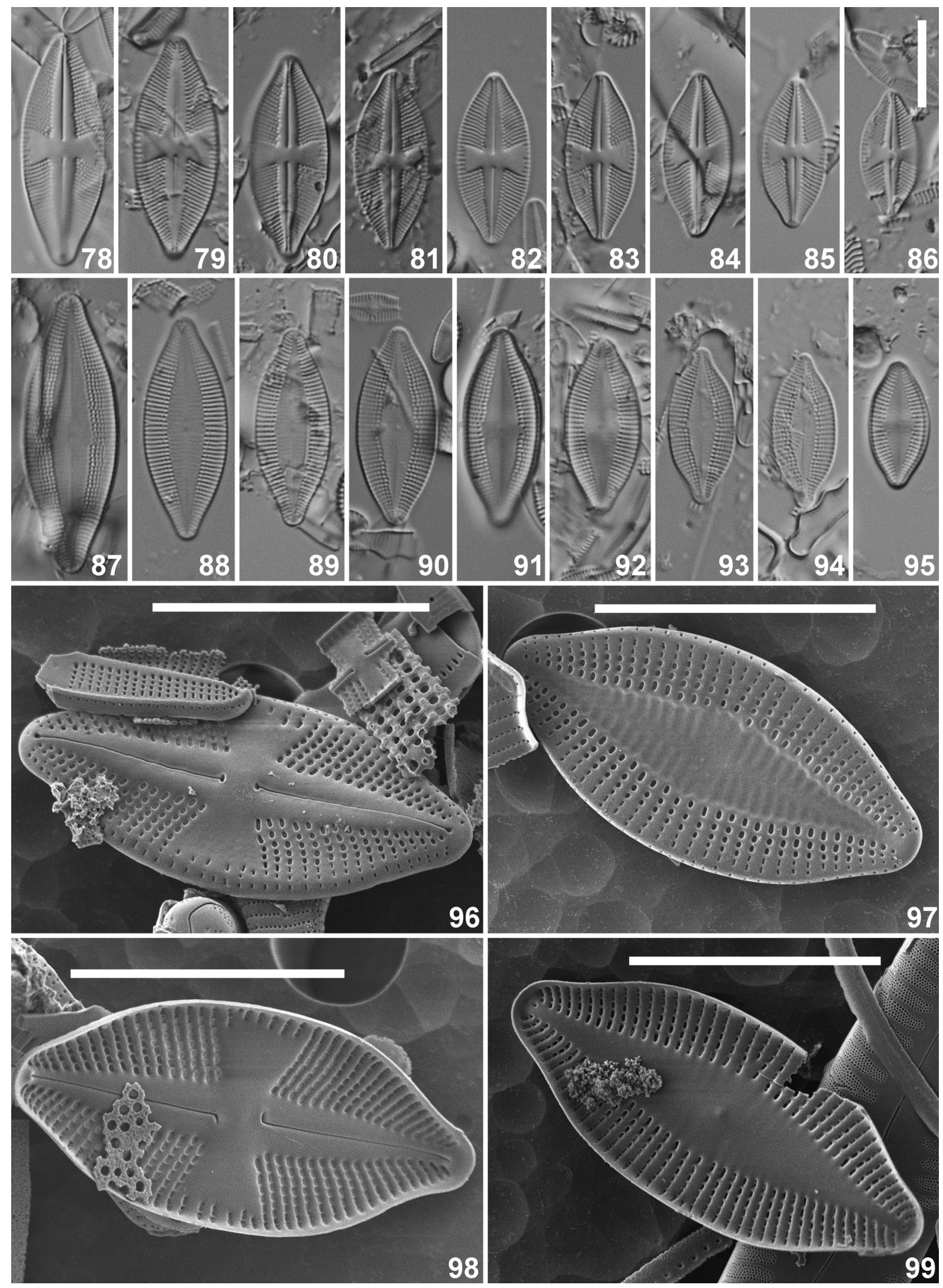

Figs 78-99. Psammothidium ellipticomanguinii Van de Vijver stat. et nom. nov., LM and SEM pictures taken from the epitype population (Sample KER-BM505, Val Studer, the Kerguelen Archipelago). Figs 78-87. LM pictures showing raphe (figs 78-86) and rapheless (Figs 87-95) valves. Fig. 96. SEM external view of an entire raphe valve. Fig. 97. SEM external view of an entire rapheless valve. Fig. 98. SEM internal view of an entire raphe valve. Fig. 99. SEM internal view of an entire rapheless valve. Scale bars represent $10 \mu \mathrm{m}$. 


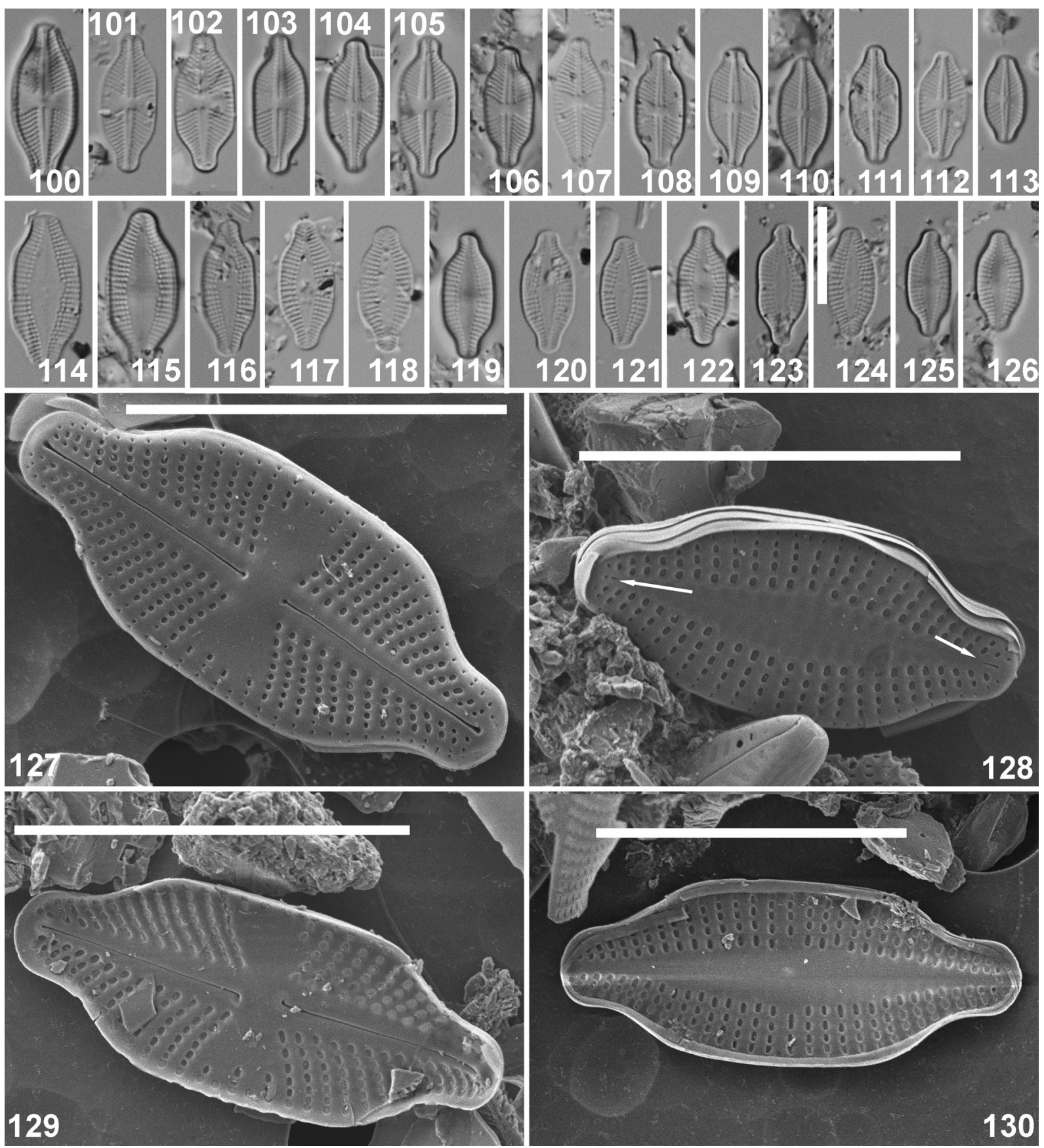

Figs 100-130. Psammothidium antarcticum Van de Vijver sp. nov., LM and SEM pictures taken from the type population (Sample HE546, Heard Island). Figs 100-126. LM pictures showing raphe (Figs 100-113) and rapheless (Figs 114-126) valves. Fig. 127. SEM external view of an entire raphe valve. Fig. 128. SEM external view of an entire rapheless valve. The arrows indicate the presence of vestigial raphe slits. Fig. 129. SEM internal view of an entire raphe valve. Fig. 130. SEM internal view of an entire rapheless valve. Scale bars represent $10 \mu \mathrm{m}$.

simple to weakly expanded. Terminal raphe fissures not discernible in LM. Striae strongly radiate and even geniculate throughout the entire valve, $22-24$ in $10 \mu \mathrm{m}$. Areolae often visible in LM.

Scanning electron microscopy (Figs 127-130): Raphe valve (Figs 127, 129): Raphe located on a weakly raised, rather narrow sternum. External raphe branches straight. Central raphe endings straight, very short, simple, almost not expanded. Terminal raphe fissures short, straight, weakly expanded. Internally, central raphe endings very short, hooked into opposite directions. Terminal endings terminating on weakly developed helictoglossae. Striae uniseriate. External areola foramina rounded to rectangular near the axial area, around 45 in $10 \mu \mathrm{m}$. Virgae wider than the striae. Terminal areolae of each stria near the valve margin very small, point-like. On the valve mantle, striae continuing with one, very small areola. Mantle striae not entirely surrounding the valve, but interrupted at the valve apices. Internally, areolae usually rectangular, occluded normally by individual hymenes 


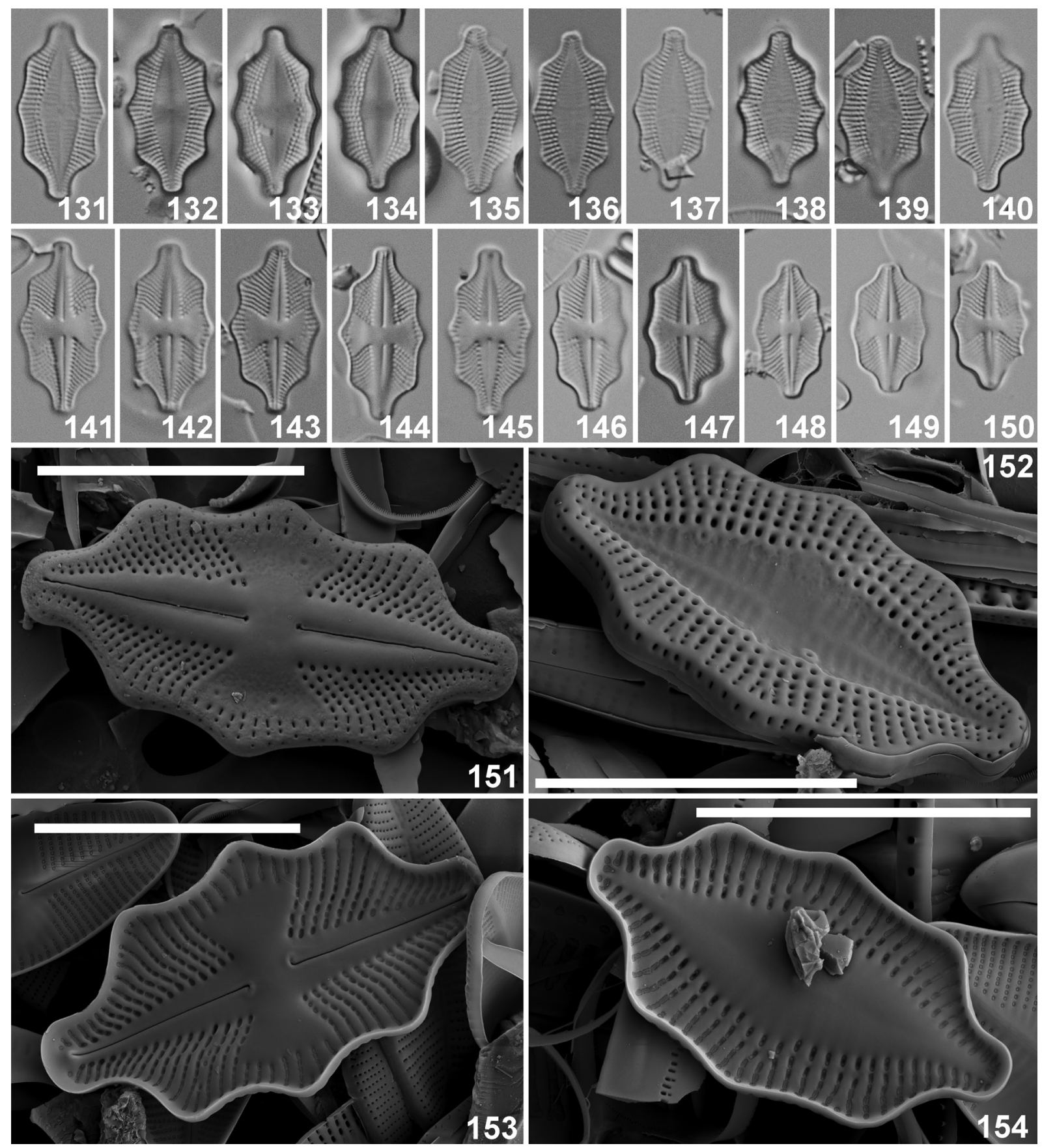

Figs 131-154. Psammothidium acutomanguinii Van de Vijver sp. nov., LM and SEM pictures taken from the type population (Sample HEQ252, Heard Island). Figs 131-150. LM pictures showing raphe (Figs 131-140) and rapheless (Figs 141-150) valves. Fig. 151. SEM external view of an entire raphe valve. Fig. 152. SEM external view of an entire rapheless valve. Fig. 153. SEM internal view of an entire raphe valve. Fig. 154. SEM internal view of an entire rapheless valve. Scale bars represent $10 \mu \mathrm{m}$.

but usually eroded. Virgae not raised, broader than the striae. Rapheless valve (Figs 128, 130): External axial and central area slightly depressed, showing ghost striae. Very small vestiges of a raphe visible on both apices (Fig. 128, arrows). Striae uniseriate composed of rather large, rectangular to rounded areolae. Areolae bordering the axial area larger than others and one terminal areolae near the valve margins very small, point-like. Internally, axial and central area smooth, flat. Areolae rectangular. Virgae not raised, slightly broader than the striae.
Holotype: BR-4546 (Meise Botanic Garden, Belgium) Isotype: PLP-355 (University of Antwerp, Belgium) Type locality: West of Lavett Buff, Heard Island, SubAntarctica, sample HE546 (leg. N.J.M.Gremmen), coll. date 21/12/2000 (53¹1'15.4"S,7331'80.1"E)

Etymology: the specific epithet refers to the wide biogeographical distribution of this species in almost the entire Antarctic Region.

Ecology and confirmed distribution: Psammothidium 

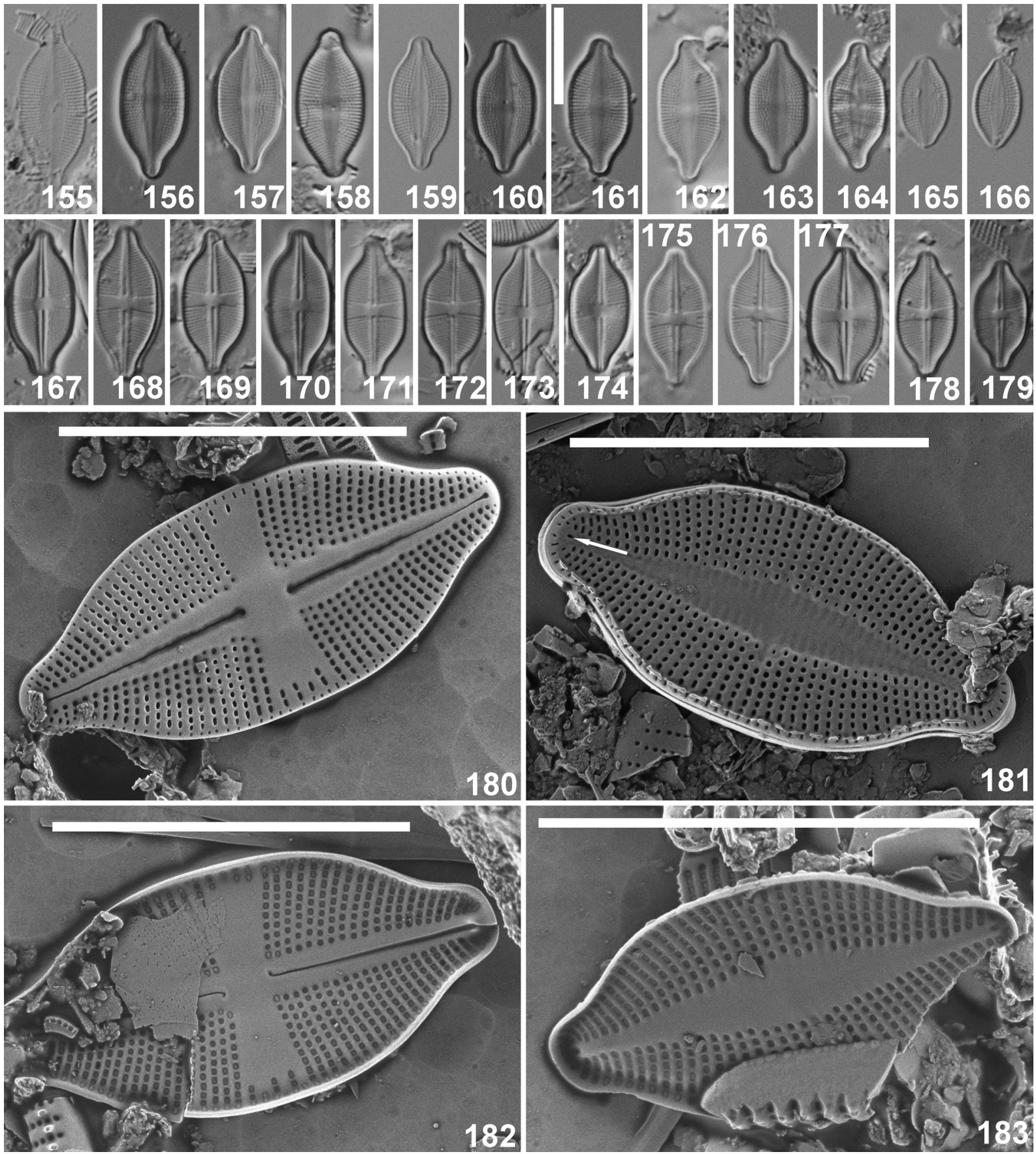

Figs 155-183. Psammothidium hodgsonii Van de Vijver et Verleyen sp. nov., LM and SEM pictures taken from the type population (Sample MAC8 LITE Macquarie Island). Figs 155-179. LM pictures showing raphe (Figs 155-166) and rapheless (Figs 167-179) valves. Fig. 180. SEM external view of an entire raphe valve. Fig. 181. SEM external view of an entire rapheless valve. The arrows indicate the presence of vestigial raphe slits. Fig. 182. SEM internal view of an entire raphe valve. Fig. 183. SEM internal view of an entire rapheless valve. Scale bars represent $10 \mu \mathrm{m}$.

antarcticum was found on several islands and archipelagos in the southern Indian Ocean. Only on the Prince Edward Islands, the species seems to be absent. Most Indian Ocean populations were observed on Heard Island and the Kerguelen Archipelago, although also on the Crozet Archipelago a small population was recorded in dried mosses on a slope near Pointe Basse on Ile de La Possession (Van de Vijver, pers. obs.). The species seems to prefer semi-dry, terrestrial moss vegetations, often located in sheltered, shaded sites such as in caves or under the overhang of a high rockface, although one large population was found on moss patches in a fellfield. The largest populations of $P$. antarcticum are however found in the Maritime Antarctic Region (as P. manguinii). ZIDAROva et al. (2016) illustrate several populations from the South Shetland Islands and James Ross Island. OpPenheIm (1994) discusses the presence of Achnanthes manguinii var. elliptica on Signy Island (South Orkney 

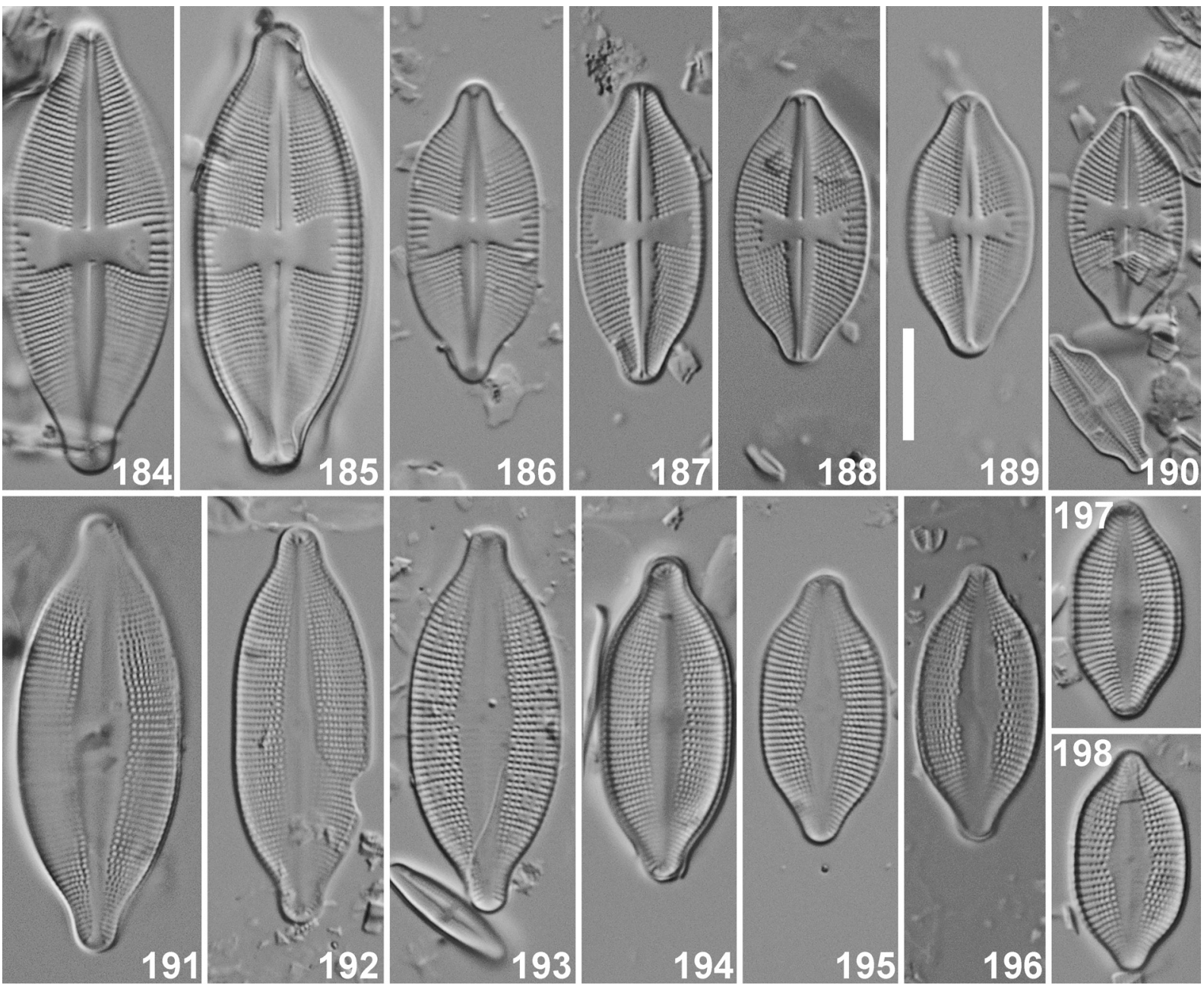

Figs 184-198. Psammothidium mannensianum Van de Vijver sp. nov., LM pictures taken from the type population (Sample VITT Campbell 2433 Island) showing raphe (Figs 184-190) and rapheless (Figs 191-198) valves. Scale bar represents $10 \mu \mathrm{m}$.

Islands), another archipelago in the Maritime Antarctic Region and shows several valves that seem to be conspecific with $P$. antarcticum. On the Falkland Islands/Islas Malvinas, similar populations were found (and identified as $P$. manguinii) (JÜTTNER \& VAN DE VIJVER 2018). The species was also observed on Campbell Island and Macquarie Island (although only in very small numbers) making this one of the most widespread Psammothidium taxa in the Antarctic Region. The populations on these southern Atlantic Ocean Islands were always found in semi-dry, terrestrial moss vegetations (ZIDAROVA et al. 2016).

\section{Psammothidium acutomanguinii sp. nov. (Figs 131-154) Description}

Light microscopy (Figs 131-150): Valves elliptical to elliptical-lanceolate with very distinctly undulating margins, showing three clear, acutely rounded, undulations, and protracted, rostrate apices. Valve dimensions $(\mathrm{n}=20)$ : length $14-19 \mu \mathrm{m}$, width 7.5-9.5 $\mu \mathrm{m}$, length/width ratio 1.7-2.0. Rapheless valve: axial area very broad, lanceolate with clear indication of ghost striae. Striae clearly uniseriate, radiate throughout the entire valve,
20-22 in $10 \mu \mathrm{m}$. Areolae well visible in LM, ca. 35 in $10 \mu \mathrm{m}$. Raphe valve: axial area gradually but distinctly widening towards the central area, almost entirely absent towards the apices. Central area very large, distinctly wedge-shaped, bordered by a large number of shortened but distinct marginal striae, hence not forming a fascia. Raphe filiform, straight with inconspicuous central and terminal endings. Striae clearly radiate to even geniculate, throughout the entire valve, $21-22$ in $10 \mu \mathrm{m}$. Areolae well discernible in LM.

Scanning electron microscopy (Figs 151-154): Raphe valve (Figs 151, 153): Raphe located on a clearly raised sternum, extending on both sides of the raphe, giving the valve face an undulating surface. External raphe branches straight lacking terminal raphe fissures. Central and terminal raphe endings short, straight, clearly expanded. Internally, central raphe endings simple, short but distinctly hooked into opposite directions. Terminal raphe endings short, terminating onto small helictoglossae. Striae uniseriate, composed of up to 10 rectangular to rounded areolae, the largest areolae bordering the axial area. Near the apices, areolae becoming very 

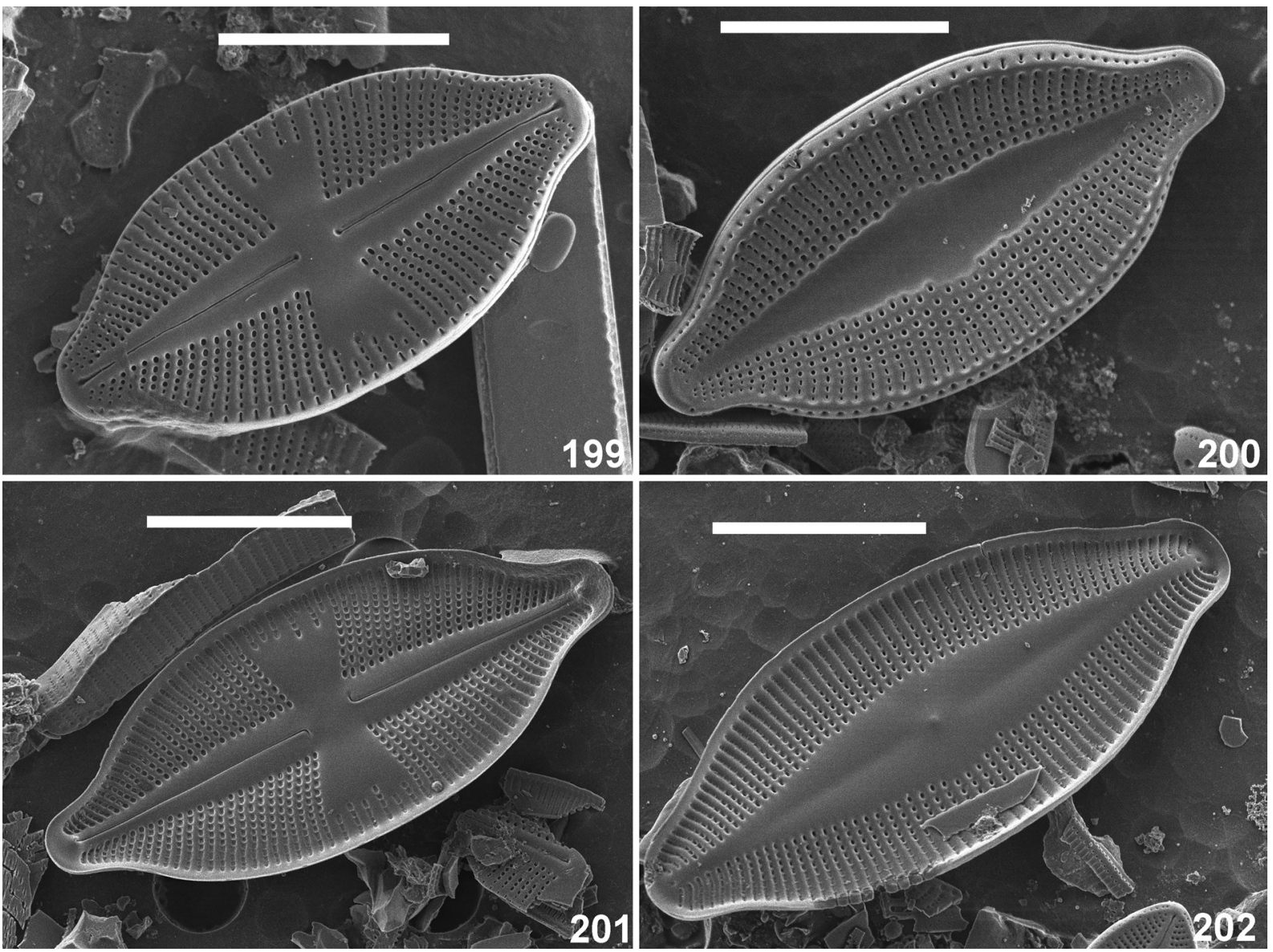

Figs 199-202. Psammothidium mannensianum Van de Vijver sp. nov., SEM pictures taken from the type population (Sample VITT Campbell 2433 Island). Fig. 199. SEM external view of an entire raphe valve. Fig. 200. SEM external view of an entire rapheless valve. Fig. 201. SEM internal view of an entire raphe valve. Fig. 202. SEM internal view of an entire rapheless valve. Scale bars represent $10 \mu \mathrm{m}$.

small, rounded. Slit-like areolae never present. Striae continuing on the mantle by one transapically elongated areola. Areolae surrounding the entire valve but interrupted at the valve apices. Internally, areolae covered by individual hymenes. Virgae weakly raised, widening from axial area towards the margins, usually broader than the striae. Undulating structure of the valve face surface clear. Rapheless valve (Figs 152, 154): Axial area very broad, lanceolate, clearly widened at the central area. Axial and central area clearly depressed showing ghost striae. Vestigial raphe slits never observed. Weakly raised apically running ridge present in the middle of the axial area. Central area never forming a fascia. Striae uniseriate, composed of 2-3 rounded to rectangular areolae, with the largest bordering the axial and central area and 1-3 weakly depressed, slit-like areolae near the margin. Areolae slightly rimmed. Virgae weakly raised, only weakly broader than the striae. Mantle areolae transapically elongated, surrounding the entire valve but shortly interrupted at the apices. Internally, areolae rectangular, covered by individual hymenes. Axial and central area relatively smooth.

Holotype: BR-4547 (Meise Botanic Garden, Belgium)
Isotype: PLP-356 (University of Antwerp, Belgium) Type locality: crater SW of Corinth Head, Heard Island, Sub-Antarctica, sample HE-Q252 (leg. N.J.M.Gremmen), coll. date 09/02/2001 (5300'33.1"S,73²4'29.9"E)

Etymology: the specific epithet refers to the close relation with $P$. manguinii and the rather acute undulations of the valve margin.

Ecology and confirmed distribution: Psammothidium acutomanguinii is present in small populations on various sub-Antarctic islands in the southern Indian Ocean. Most populations were found on Heard Island, the most southern of all Indian Ocean islands. The largest population (=type population) was collected from a Brachythecium and Pseudoleskea vegetation growing on a damp overhanging rock wall inside the crater. The sampling site was sheltered and clearly shaded. The sample was dominated by Psammothidium investians (Carter) Bukhtiyarova, an unknown Ferocia species and Pinnularia obscura Krasske. Other populations were found on Ditrichum patches in feldfields, a Brachythecium mat in a small, shaded and sheltered cave or on small Dicranoweisia cushions on a vertical rockface. The relative abundance of all these populations never exceeded 5\%. On the other islands, only very sporadically, a handful of valves were found 


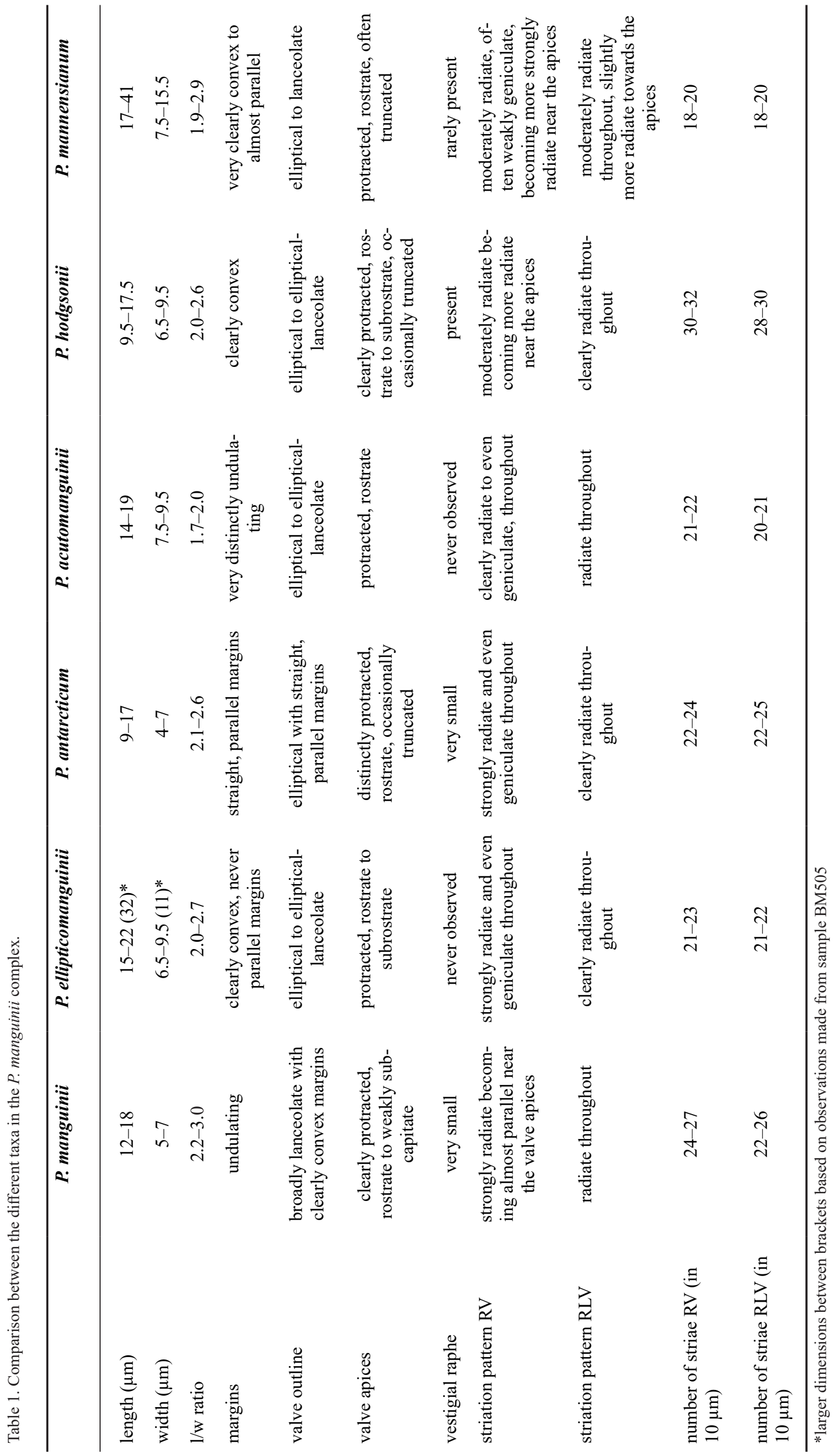


in the samples (relative abundance less than $0.05 \%$ ).

Psammothidium hodgsonii Van de Vijver et Verleyen sp. nov. (Figs 155-183)

Description

Light microscopy (Figs 155-179): Valves elliptical to elliptical-lanceolate with clearly convex margins and clearly protracted, rostrate to subrostrate, occasionally truncated, apices. Valve dimensions $(n=20)$ : length 9.5-17.5 $\mu \mathrm{m}$, width 6.5-9.5 $\mu \mathrm{m}$, length/width ratio 2.0-2.6. Rapheless valve: Axial area rather broad, lanceolate forming a broad central area. Central area never forming a fascia. Striae uniseriate, $28-30$ in 10 $\mu \mathrm{m}$, clearly radiate throughout the entire valve. Areolae discernible in LM, ca. 35 in $10 \mu \mathrm{m}$. Raphe valve: Axial area very narrow, linear, almost not widening towards the central area. Central area rather narrow, almost rectangular to weakly wedge-shaped, bordering by several shortened marginal striae, never forming a complete fascia. Raphe filiform, straight with simple central and terminal endings? Striae moderately radiate becoming more radiate near the apices, $30-32$ in $10 \mu \mathrm{m}$. Areolae not discernible in LM.

Scanning electron microscopy (Figs 180-183): Raphe valve (Figs 180, 182): Axial area clearly raised, thickened, very slightly widening towards the central area. Marginal central striae composed of 1-2 small areolae. External raphe branches with simple to weakly thickened central endings. Terminal raphe fissures very short with weakly expanded terminal pores. Striae uniseriate, composed of small, rounded areolae. Towards the valve margins, areolae becoming more rectangular, almost never slitlike. Small, point-like terminating the striae, continuing onto the mantle. Internally, central raphe endings short, clearly hooked. Areolae covered by individual hymenes. Rapheless valve (Figs 181, 183): Axial area weakly depressed showing a clearly raised ridge running apically in the middle of the axial area. Central area formed by widening of the axial area, never forming a fascia. Small vestigial raphe present on the apices (Fig. 181, see arrows). Striae uniseriate, composed of relatively large, rounded to rectangular areolae. Areolae bordering the axial and central area larger. Slit-like marginal areolae never present. Occasionally, very small, rounded areolae scattered between the normal areolae, usually near the axial area or the valve margins. Mantle areolae transapically elongated, surrounding the entire valve except at the valve apices where a small gap can be noticed. Virgae never raised, clearly larger than the striae. Near the valve face/mantle junction, a series of plate-like, thin, blunt spines visible, often arranged forming a continuous rim surrounding the valve.

Holotype: BR-4548 (Meise Botanic Garden, Belgium) Isotype: PLP-357 (University of Antwerp, Belgium) Type locality: Macquarie Island, Sub-Antarctica, sample MAC8 LITE (leg. D. Hodgson \& W. Van Nieuwenhuyze), coll. date 28/11/2013 (5442'59.6"S,15849'55.3"E)
Etymology: the species is named after our friend and colleague Dr. Dominic Hodgson (British Antarctic Survey, Cambridge, UK) to honor him for his outstanding work on the ecology and paleo-ecology of freshwater ecosystems in the entire Antarctic Region.

Ecology and confirmed distribution: The new species was only found on Macquarie Island in the southern Pacific Ocean. The largest population was found in the littoral sediment slightly acidic lake ( $\mathrm{pH}$ 6.4) with low conductivity $\left(<150 \mu \mathrm{S} . \mathrm{cm}^{-1}\right)$. The sample was dominated by Stauroforma exiguiformis (Lange-Bertalot) Flower et al. and several Psammothidium taxa such as $P$. cf. levanderi (Hustedt) Czarnecki and P. subatomoides (Hustedt) Bukhtiyarova et Round. Other (very small) populations were observed in terrestrial mosses. Due to confusion with $P$. manguinii in older (not verifiable) records, it is unclear whether the species is more widespread. It was not observed on Campbell Island (Van de Vijver, pers. obs.)

Psammothidium mannensianum sp. nov. (Figs 184-202) Description

Light microscopy (Figs 184-198): Valves elliptical to lanceolate with very clearly convex to almost parallel margins and protracted, rostrate, often truncated apices. Valve dimensions $(n=20)$ : length $17-41 \mu \mathrm{m}$, width 7.5-15.5 $\mu \mathrm{m}$, length/width ratio 1.9-2.9. Raphe valve: Axial area narrow, linear, widening gradually towards the central area. Near the apices, axial area becoming suddenly very narrow, almost non-existing. Central area weakly wedge-shaped, never forming a fascia due to several (up to 7) shortened, but still distinct marginal striae. Raphe filiform, straight with simple central raphe endings and in LM non-discernible terminal raphe fissures. Striae moderately radiate, often weakly geniculate, becoming more strongly radiate near the apices, 18-20 in $10 \mu \mathrm{m}$. Striae composed of very small, but in LM still discernible areolae. Rapheless valve: Axial area broad, lanceolate, widening in the middle, forming a rather broad central area. Occasionally raised apically running ridge in the middle of the axial area visible. Central area never forming a fascia. Striae uniseriate, $18-20$ in 10 $\mu \mathrm{m}$, moderately radiate throughout, slightly more radiate towards the apices, composed of relatively large, clearly discernible areolae.

Scanning electron microscopy (Figs 199-202): Raphe valve (Figs 199, 201): Axial area broad, lanceolate, gradually widening towards the central area. Central area bordered by up to 7 shortened, but still distinct (composed of up to 5 small areolae) marginal striae. External raphe branches weakly undulating. Central endings straight, weakly expanded. Terminal raphe fissures short with expanded terminal pores. Striae uniseriate, composed of a large number of rounded, near the axial area rectangular, areolae. Several slit-like areolae terminating the striae near the valve margins. At the apices, several very small, point-like areolae present. Internally, areolae covered by 
individual hymenes. Central raphe endings short, clearly hooked into opposite directions. Terminal raphe endings terminating onto small helictoglossae. Rapheless valve (Figs 200, 202): Axial area clearly depressed, with very faint ghost striae. Valve face/mantle junction slightly thickened forming a rim surrounding the valve. Striae uniseriate composed of large, rounded areolae near the axial area and 2-4 short, slit-like areolae near the valve margins. At the apices, several very small, point-like areolae present. Mantle areolae slit-like, absent at the apices. Very small vestigial raphe slits rarely present.

Holotype: BR-4549 (Meise Botanic Garden, Belgium) Isotype: PLP-358 (University of Antwerp, Belgium) Type locality: Mount Honey, Campbell Island, SubAntarctica, sample VITT 2433 (leg. D. Vitt), coll. date 31/12/1969 (52³4'S, $\left.169^{\circ} 10^{\prime} \mathrm{E}\right)$.

Etymology: the species is named after my dear friend Mr. Patrick Mannens (Meise Botanic Garden, Belgium) to thank him for his efforts in maintaining the precious orchid collection of the Meise Botanic Garden.

Ecology and confirmed distribution: Up to now, the new species was only found in several samples on Campbell Island, located in the southern Pacific Ocean. The largest population was found in a Rhacocarpus purpurascens vegetation on rocks on the north-northwest slope of Mt. Honey, collected close to the summit. The species co-occurred with $P$. manguinii.

\section{Discussion}

As previously mentioned in the introduction, Psammothidium manguinii was for a long time considered representing only one, morphologically very variable, species. Manguin (in BouRRELLY \& MANGUIN 1954) separated some valves based on their more elliptical valve outline, a larger valve width and a lower number of striae than the var. elliptica. Le CoHu \& MAillard (1983), LANGE-Bertalot \& Krammer (1989), VAN DE ViJver et al. (2002) and LE CoHu (2005), however, doubted this separation stating that there was no morphological difference between the nominate form and the var. elliptica. In the present study, a detailed analysis was made of the type material of both $A$. manguinii and $A$. manguinii var. elliptica completed with a thorough analysis of more than 100 populations reported as Psammothidium manguinii in the sub-Antarctic and Maritime Antarctic Region (VAN DE VIJVER et al. 2002, 2004, 2008 + unpublished results; ZIDAROva et al. 2016). This resulted in the description of 4 new taxa and a critical analysis of the former var. elliptica. Table 1 shows the main morphological features of the different taxa.

Contrary to earlier publications, Achnanthes manguinii var. elliptica is considered as an independent taxon that should be clearly separated from P. manguinii. The differences between both taxa are sufficient to raise the variety elliptica up to species level:

\section{Psammothidium ellipticomanguinii Van de Vijver nom. et stat. nov.}

Basionym: Achnanthes manguinii var. elliptica Manguin in BourRELLY \& MANGUIN 1954, Mémoires de l'Institut scientifique de Madagacar série $\mathrm{B}$, Tome V, p. 22, figs 15 a \& b.

Both taxa can mainly be separated based on their valve outline with $P$. manguinii showing clearly undulating margins and $P$. ellipticomanguinii having typical elliptical, rounded, convex margins. Psammothidium ellipticomanguinii has larger valves with a valve width exceeding usually the valve width of $P$. manguinii (6.5-11 $\mu \mathrm{m}$ vs. 5-7 $\mu \mathrm{m})$. Additionally, the central area in $P$. ellipticomanguinii is larger with a more radiate striation pattern when compared with $P$. manguinii. The $\mathrm{RV}$ in $P$. ellipticomanguinii has more punctate striae where in $P$. manguinii the areolae of the RV are only very rarely visible in LM. Both taxa co-occur on the southern Indian Ocean islands, but an overlap between both taxa is never observed, and both taxa can be easily recognized. Intermediate forms, as incorrectly stated in LANGE-BERTALOT \& KRAMMER (1989) and VAN DE VIJVER et al. (2002) were never observed.

The historical sample that Manguin used for the description of $A$. manguinii var. elliptica contained in fact two different taxa (apart from the nominate $P$. manguinii). One of the taxa showed a clear resemblance with the drawings Manguin published in BouRRELLY \& Manguin (1954, figs 15a\&b) with convex margins and represents $P$. ellipticomanguinii. The second taxon however, shows absolutely no resemblance to the drawings in BourRelly \& MANGUIN (1954) and is also quite different from $P$. ellipticomanguinii based its valve outline with the never undulating, clearly parallel, straight valve margins, the relative low valve width (usually $<6.5 \mu \mathrm{m}$ ), the pronounced rostrate apices and the higher stria density (up to 25 striae in $10 \mu \mathrm{m}$ ). These differences justify its separation from all other taxa as a separate species, $P$. antarcticum, in the $P$. manguinii complex. Based on all published (and illustrated) records and unpublished observations, it is the most widespread of all taxa in the P. manguinii complex. The largest concentrations of records are from the Maritime Antarctic Region where $P$. antarcticum is not only present on every island and archipelago but also the only representative of the $P$. manguinii complex (OPPENHEIM 1994; ZIDAROVA et al. 2016). On the other hand, the species is present but less frequent on the southern Indian Ocean islands.

Of all 5 taxa, split off from P. manguinii, only P. acutomanguinii shows an undulating valve outline. Both taxa can however be very easily separated based on morphometrical differences. The length/width ratio is clearly different between both taxa with $P$. acutomanguinii always having much wider valves resulting in a lower L/W ratio, 
being always $<2.0$ contrary to $P$. manguinii that shows a $\mathrm{L} / \mathrm{W}$ ratio of $>2.2$. The valve outline in $P$. manguinii is therefore always more elongated and typically broadly lanceolate whereas $P$. acutomanguinii presents a sturdier outline with an elliptical to elliptical-lanceolate shape. The SEM observations show some additional differences. The raphe valves in Psammothidium acutomanguinii possess striae with a larger number of areolae (up to 10) whereas in P. manguinii a maximum of only 5-6 areolae is found. LE COHU \& MAILlARD (1983) showed several valves of $P$. acutomanguinii but reported them as A. manguinii. Nevertheless, it shows that the species is also confirmed as present on the Kerguelen Archipelago.

Two taxa were only found on the southern Pacific Ocean islands: $P$. hodgsonii and $P$. mannensianum. Psammothidium hodgsonii is the only taxon of the $P$. manguinii complex showing spines on its rapheless valve. The presence of spines is quite rare in monoraphid diatoms although several taxa in the genus Planothidium were previously reported having spines on their rapheless valves. Apart from Planothidium cyclophorum (Heiden) Van de Vijver and $P$. densistriatum Van de Vijver et Beyens, both only known from the sub-Antarctic Region, a third species, Planothidium lilianeanum Van de Vijver, was recently described from the Kerguelen Archipelago (VAN DE VIJVER et al. 2018). In the genus Psammothidium however, spines have not been reported till now. Psammothidium hodgsonii shows a faint resemblance to $P$. ellipticomanguinii based on valve outline and general outlook. However, apart from the presence of spines, several obvious differences can be pointed out. Psammothidium hodgsonii has the highest stria density of all taxa in the complex exceeding often 30 striae in 10 $\mu \mathrm{m}$ whereas all other taxa never showed more than 27 striae in $10 \mu \mathrm{m}$. On the rapheless valve, vestigial raphe slits are more often observed than on any other taxon from this complex. Psammothidium mannensianum is the largest species in the entire complex. Valves reaching 40 $\mu \mathrm{m}$ in length and $15 \mu \mathrm{m}$ in width are not rare, which is almost double than any other taxon in the P. manguinii complex. Psammothidium ellipticomanguinii shows some resemblance but this is mostly based on valve outline although the latter has more rounded, convex margins whereas $P$. mannensianum has a parallel part in its margins giving the valves a more elongated outlook. Psammothidium manguinii is often observed in samples were $P$. mannensianum was found, and the difference in valve dimensions is very striking. The stria density on the other hand is the lowest of all taxa in the complex (18-20 in $10 \mu \mathrm{m})$.

\section{ACKNOWLEDGEMENTS}

Dr. N.J.M. Gremmen is thanked for providing the samples of Heard Island, the Kerguelen Archipelago and the Prince Edward Islands. Fieldwork on Macquarie Island was carried out by Dominic Hodgson, Steve Roberts and Wim Van Nieuwenhuyze with logistic support from the Australian Antarctic Division (Project 4156) and the UK Natural Environment Research Council (NE/K004514/1). Dr. Dale Vitt is thanked for the samples from Campbell Island. Further sampling on the Crozet Archipelago and the Kerguelen Archipelago was made possible with the logistic and financial support of the Institut Polaire Français - Paul-Emile Victor (IPEV) in the frame of the Terrestrial Ecology program 136 (Yves Frenot \& Marc Lebouvier). This study was further supported by the BELSPO MICROBIAN project to visit the National History Museum in London, UK. ALEx BALL and the staff of the IAC laboratory at the Natural History Museum are thanked for his help with the scanning electron microscopy. The Hustedt Collection in Bremerhaven and the Muséum d'Histoire Naturelle de Paris are thanked for providing the historical material of Hustedt and Manguin. The British Antarctic Survey (Cambridge, UK) is thanked for allowing the use of the Campbell Island material from their collection. Mr. Myriam de Haan is thanked for technical assistance preparing the samples.

\section{REFERENCES}

Bourelly, P. \& Manguin, E. (1954): Contribution a la Flore Algale d'eau Douce des Iles Kerguelenthe Kerguelen Archipelago. - Mémoires de l'Institut Scientifique de Madagascar, Séries B., Vol. V, 5-58+11 pls.

Bukhtiyarova, L. \& Round, F.E. (1996): Revision of the genus Achnanthes sensu lato. Psammothidium, a new genus based on A. marginulatum. - Diatom Research 11: 1-30.

Hassan, G.S.; Tietze, E.; De Francesco, C.G. \& Cristini, P.A. (2011): Problems and potentialities of using diatoms as paleoclimatic indicators in Central Argentina. Diatoms: Ecology and Life Cycle. - pp. 185-217, Nova Science Publishers, New York.

Hendey, N.I. (1964): An introductory account of the smaller algae of British coastal waters. Part V. Bacillariophyceae (Diatoms). - London: her Majesty's Stationery Office, $317 \mathrm{pp}+44$ plates.

Hickman, M. \& VitT, D.H. (1973): The aerial epiphytic diatom flora of moss species from subantarctic Campbell Island. - Nova Hedwigia 24: 443-458.

Hustedt F. (1952): Neue und wenig bekannte Diatomeen. IV. - Botaniska Notiser 1952: 366-410.

JÜTTNER, I. \& VAN DE ViJVER, B. (2018): A preliminary account of diatom taxa in the Falkland Islands. -51 pp., Shackleton Scholarschip Report.

KellogG, T.B. \& KellogG, D.E. (2002): Non-marine and littoral diatoms from Antarctic and Subantarctic regions. Distribution and updated taxonomy. - Diatom Monographs 1: 1-795.

Kingston, J.C. (2003): Araphid and Monoraphid Diatoms. - In: Wehr, J.D. \& Sheath, R.G. (eds): Freshwater Algae of North America, Ecology and Classification. - pp. 595-636, San Diego, Academic Press.

Kopalová, K.; Zidarova, R. \& VAN de Vijver, B. (2016): Four new monoraphid diatom species (Bacillariophyta, Achnanthaceae) from the Maritime Antarctic Region. - European Journal of Taxonomy 217: 1-19.

Krasske, G. (1949): Subfossile Diatomeen aus den Mooren Patagoniens und Feuerlands. - Annales Academiae Scientiarum Fennicae, Sarja Series A. IV, Biologica. 14: 1-95.

Kulikovskiy, M.; Lange-Bertalot, H. \& Witkowski, A. (2013): Gliwiczia gen. nov. a new monoraphid diatom genus from Lake Baikal with a description of four species new for science. - Phytotaxa 109: 1-16.

Kulikovskiy, M.S.; Lange-Bertalot, H. \& KuZnetsova, I.V. (2015): Lake Baikal: hotspot of endemic diatoms II. - Iconographia Diatomologica 26: 1-656.

Lange-Bertalot, H. \& Krammer, K. (1989): Achnanthes eine 
Monographie der Gattung. - Bibliotheca Diatomologica 18: $1-393$.

Le Cohu, R. \& Maillard, R. (1983): Les diatomées monoraphidées des îles Kerguelen. - Annales de Limnologie 19: 143-167.

Le CoHU, R. (2005): Révision des principales espèces dulçaquicoles d'Achnanthales (Bacillariophyta) des îles subantarctiques de Kerguelen. - Algological Studies 116: 79-114.

OpPENHEIM, D.R. (1994): Taxonomic studies of Achnanthes (Bacillariophyta) in freshwater maritime antarctic lakes. - Canadian Journal of Botany 72: 1735-1748.

Romero, O.E. \& VAN DE ViJVER, B. (2011): Cocconeis crozetensis, a new monoraphid diatom from subantarctic freshwater and moss habitats. - Diatom Research 26: 89-98.

Ross, R.; Cox, E.J.; Karayeva, N.I.; ManN, D.G.; PAdDock, T.B.B.; SimONSEN, R. \& Sims, P.A. (1979): An amended terminology for the siliceous components of the diatom cell. - Nova Hedwigia, Beihefte 64: 513-533.

Round, F.E. \& Bukhtiyarova, L. (1996): Four new genera based on Achnanthes (Achnanthidium) together with a re-definition of Achnanthidium. - Diatom Research 11: 345-361.

Round, F.E.; Crawford, R.M. \& Mann, D.G. (1990): The diatoms. Biology \& morphology of the genera. - 747 pp., Cambridge University Press, Cambridge.

Round, F.E \& BAsson, P.W. (1997): A new monoraphid diatom genus (Pogoneis) from Bahrain and the transfer of previously described species $A$. hungarica and $A$. taeniata to new genera. - Diatom Research 12: 71-81.

VAN DE ViJver, B. \& Beyens, L. (1996): Freshwater diatom communities of the Strømness Bay area, South Georgia. - Antarctic Science 8: 359-368.

VAN DE ViJVer, B. \& Beyens, L. (1997): The epiphytic diatom flora of mosses from Strømness Bay area, South Georgia. - Polar Biology 17: 492-501.

VAN DE ViJVer, B.; Ledeganck, P. \& Beyens, L. (2001): Habitat preferences in freshwater diatom communities from sub-Antarctic Îles Kerguelen. - Antarctic Science 13: 28-36.
VAn de VijVer, B.; Frenot, Y. \& Beyens, L. (2002): Freshwater diatoms from Ile de la Possession (Crozet Archipelago, Subantarctica). - Bibliotheca Diatomologica 46: 1-412.

VAn de ViJver, B.; Beyens, L.; Vincke, S., Gremmen, N.J.M. (2004): Moss-inhabiting diatom communities from Heard Island, sub-Antarctic. - Polar Biology 27: 532-543.

VAn de ViJver, B.; Gremmen, N. \& Smith, V. (2008): Diatom communities from the sub-Antarctic Prince Edward Islands: diversity and distribution patterns. - Polar Biology 31: 795-808.

VAN de Vijver, B.; Wetzel, C.; Kopalová, K.; Zidarova, R. \& ECTOR, L. (2013): Analysis of the type material of Achnanthidium lanceolatum Brébisson ex Kützing (Bacillariophyta) with the description of two new Planothidium species from the Antarctic Region. Fottea 13: 105-117

VAN DE ViJver, B. \& Kopalová, K. (2014): Four Achnanthidium species (Bacillariophyta) formerly identified as Achnanthidium minutissimum from the Antarctic Region. - European Journal of Taxonomy 79: 1-19

VAn de Vijver, B.; Kopalová, K.; Zidarova, R. (2016). Revision of the Psammothidium germainii complex (Bacillariophyta) in the Maritime Antarctic Region. Fottea. 16: 145-156.

VAn de Vijver, B.; Wetzel, C.E. \& Ector, L. (2018): Analysis of the type material of Planothidium delicatulum (Bacillariophyta) with the description of two new Planothidium species from the sub-Antarctic Region. - Fottea 18: 200-211.

VAN DER WerfF, A. (1955): A new method for cleaning and concentrating diatoms and other organisms. Verhandlungen der Internationalen Vereinigung für theoretische und angewandte Limnologie 12: 276-277.

Zidarova, R.; Van de Vijver, B.; Mataloni, G.; Kopalová, K. \& Nedbalová, L. (2009): Four new freshwater diatom species (Bacillariophyceae) from Antarctica. - Cryptogamie Algologie. 30: 295-310.

Zidarova, R.; Kopalova, K. \& Van de Vijver, B. (2016): Diatoms from the Antarctic Region. I: Maritime Antarctica. - Iconographia Diatomologica 24: 1-509.

(C) Czech Phycological Society (2019)

Received December 17, 2018

Accepted January 7, 2019 